\title{
PENGEMBANGAN APLIKASI SISTEM CERDAS UNTUK MENENTUKAN PEMINATAN JURUSAN DI UNIVERSITAS DIPONEGORO BAGI SISWA SEKOLAH MENENGAH ATAS
}

\author{
Imaduddin Abdul Rahim. ${ }^{1)}$, Oky Dwi Nurhayati ${ }^{2)}$, Kurniawan Teguh Martono \\ Program Studi Sistem Komputer, Fakultas Teknik, Universitas Diponegoro, \\ Jln. Prof. Sudharto, Tembalang, Semarang, Indonesia \\ email : imaduddin.ar@gmail.com
}

\begin{abstract}
Almost in every aspect of life, people are always faced with several options. Making the right decision will greatly affect our lives in the future. Problems in decision making are also experienced by high school students or high school who want to continue their education to a higher level, namely the University. University is a choice of formal education for high school students who will continue to the higher education. Students who wish to proceed to the University of Diponegoro University will particularly difficult because of the many options available majors. Often some high school students who have a student do not get along with their chosen majors, this course will make their declining interest in learning. As an information technology solution that exists today can be utilized to see the interest of the students so that mismatch and vacillation in the selection of majors can subtract. The purpose of making the determination of intelligent systems majors at Diponegoro University, among others, is, to develop an intelligent software that can help high school students determine the appropriate department at the University of Diponegoro.

Intelligent system implements advanced tracing method or Forward Chaining to determine Diponegoro University majoring in accordance with the interests of the students. This can be done by making questions like questionnaires with a variety of options to be able to know the interests of students. Forward Chaining is a method in the form of a strategy to predict or find the solution of a problem that starts with a set of known facts, then lower the new fact that the premise is based on the rule matches the known facts. The system is made to work on a desktop base with Visual Basic programming language, and the database used is Microsoft Access.

The results of testing this systems shows that all the features contained in this system can work well, and are able to provide the appropriate department recommendations, as well as ranked by passing grade and information about majors contained in Diponegoro University to the users of intelligent systems is particularly students from high school.

Keywords : Intelligent System, Forward Chaining, Senior High School, Decision Making, Universitas Diponegoro, Visual Basic, Microsoft Access
\end{abstract}

\section{PENDAHULUAN}

Hampir dalam setiap aspek kehidupan, manusia selalu dihadapkan pada beberapa pilihan. Pengambilan keputusan yang tepat akan sangat berpengaruh pada kehidupan kita kedepannya. Permasalahan dalam pengambilan keputusan juga dialami oleh siswa Sekolah Menengah Atas atau SMA yang ingin melanjutkan pendidikannya ke jenjang yang lebih tinggi, yaitu Universitas.

Universitas merupakan pilihan pendidikan formal bagi siswa SMA yang akan melanjutkan kejenjang yang lebih tinggi. Siswa yang ingin melanjutkan ke Universitas khususnya Universitas Diponegoro akan sulit karena banyaknya pilihan jurusan yang ada.
Sering dijumpai siswa SMA yang telah menjadi mahasiswa merasa tidak cocok dengan jurusan yang mereka pilih, hal ini tentunya akan membuat minat belajar mereka menurun.

Oleh karena itu dalam Tugas Akhir ini dikembangkanlah suatu sistem cerdas berbasis pengetahuan yang mengimplementasikan metode perunutan maju atau Forward Chaining untuk menentukan jurusan di Universitas Diponegoro yang sesuai dengan minat dari siswa. Hal ini dapat dilakukan dengan cara membuat pertanyaanpertanyaan seperti kuisioner yang disertai berbagai pilihan untuk dapat mengetahui minat dari siswa. Metode Forward Chaining (Perunutan Maju) yaitu metode yang berupa strategi untuk memprediksi atau mencari solusi dari suatu masalah yang dimulai dengan sekumpulan fakta yang diketahui, kemudian menurunkan fakta baru berdasarkan aturan yang premisnya cocok dengan fakta yang diketahui.

Tujuan pembuatan sistem cerdas penentuan jurusan di Universitas Diponegoro ini antara lain adalah untuk membantu mempermudah siswa SMA dalam memilih jurusan di Universitas Diponegoro yang sesuai dengan minat siswa, dan juga menciptakan dan mengimplementasikan sebuah perangkat lunak sistem cerdas yang dapat membantu siswa SMA menentukan jurusan yang tepat di Universitas Diponegoro.

Dalam penulisan tugas akhir ini, penulis membatasi pembahasan dalam hal berikut :

a. Sistem bekerja pada basis desktop dengan bahasa pemrograman Visual Basic, dan basis data yang digunakan adalah Microsoft Access 2007.

b. Lingkup kerja sistem adalah jurusan atau program studi S1 yang ada pada Universitas Diponegoro.

c. Penentuan jurusan yang dilakukan dalam sistem ini disesuaikan berdasarkan peminatan siswa sebagai pengguna.

d. Sistem ini menggunakan Metode dari Sistem Pakar yaitu Forward Chaining (Perunutan Maju).

e. Sistem ini bersifat prototype versi release yang sudah dapat digunakan tetapi memungkinkan masih adanya bug. 


\section{DASAR TEORI}

2.1 Kecerdasan Buatan dan Sistem Pakar Artificial Intelligence atau Kecerdasan Buatan adalah salah satu bidang ilmu komputer yang mendaya gunakan komputer sehingga dapat berperilaku cerdas seperti layaknya manusia. Ilmu Komputer tersebut mengembangkan perangkat lunak dan perangkat keras untuk bisa menirukan tindakan dari manusia.

Kecerdasan buatan dapat menyelesaikan permasalahan dengan menggunakan komputer untuk memecahkan masalah yang komplek dengan cara mengikuti proses penalaran manusia. Salah satu teknik kecerdasan buatan yang menirukan proses penalaran manusia adalah sistem pakar.

\subsection{Sistem Cerdas}

Sistem cerdas merupakan program AI (Artificial Intelligence) atau kecerdasan buatan yang menggabungkan basis pengetahuan dengan mesin inferensi. Ini merupakan bagian perangkat lunak spesialisasi tingkat tinggi atau bahasa pemrograman tingkat tinggi (High Level Language). Sistem cerdas dapat mengadopsi sebagian kecil dari tingkat kecerdasan manusia, antara lain adalah kemampuan untuk dilatih, mengingat kembali kondisi yang pernah dialami, mengolah data-data untuk memberikan aksi yang tepat sesuai yang telah diajarkan, dan kemampuan menyerap kepakaran seorang ahli melalui perintah yang dituliskan dalam sebuah bahasa pemrograman tertentu.

\subsection{Universitas Diponegoro}

Universitas Diponegoro yang lebih dikenal dengan singkatan UNDIP, adalah sebuah Perguruan Tinggi di Jawa Tengah, Indonesia, yang didirikan pada tahun 1956 sebagai Perguruan Tinggi Swasta dan baru mendapat status sebagai Perguruan Tinggi Negeri pada tahun 1961. Saat ini Universitas Diponegoro mengelola Program Studi yang terdiri atas :

1. Program Diploma (D3) sejumlah 21 program studi D3.

2. Program Sarjana (S1) dan yang setara yang berjumlah 47 program studi S1.

3. Program Magister (S2) yang terdiri atas 26 program studi S2.

4. Program Doktor (S3) terdiri atas 8 program studi Doktor.

5. Program Profesi terdiri atas 4 program studi Profesi.

6. Program Spesialis 1 terdiri atas 15 program studi Spesialis 1 .
Dalam sistem yang dikembangkan ini cakupan program studi yang digunakan hanya program studi S1 (Sarjana) saja, dikarenakan peminat yang paling tinggi serta jumlah program studi terbanyak diantara program lainnya, dan sampai saat ini ada 11 fakultas di Universitas Diponegoro, yaitu Fakultas Hukum dengan 1 program studi, Fakultas Ekonomika dan Bisnis dengan 3 program studi, Fakultas Teknik dengan 12 program studi, Fakultas Kedokteran dengan 3 program studi, Fakultas Peternakan dan Pertanian dengan 4 program studi, Fakultas Ilmu Budaya dengan 4 program studi, Fakultas Ilmu Sosial dan Ilmu Politik dengan 5 program studi, Fakultas Sains dan Matematika dengan 6 program studi, Fakultas Perikanan dan Ilmu Kelautan dengan 6 program studi, serta Fakultas Psikologi dengan 1 program studi.

\subsection{Visual Basic}

Microsoft Visual Basic merupakan sebuah bahasa pemrograman yang menawarkan Integrated Development Environment (IDE) visual untuk membuat program perangkat lunak berbasis sistem operasi Microsoft Windows dengan menggunakan model pemrograman (COM). Visual Basic pertama kali ditemukan oleh Alan Cooper pada tahun 1991. Visual Basic secara umum digunakan untuk membangun suatu program dengan menggunakan bahasa pemrograman BASIC, namun sudah menggunakan user interface sehingga memudahkan programmer pemula.

\subsection{Microsoft Office Access}

Microsoft Office Access merupakan penyimpanan basis data atau database yang dikembangkan oleh Microsoft, aplikasi ini merupakan aplikasi basis data komputer relasional yang ditujukan untuk kalangan rumahan dan perusahaan kecil hingga menengah.. Aplikasi ini menggunakan mesin basis data Microsoft Jet Database Engine, dan juga menggunakan tampilan grafis yang intuitif sehingga memudahkan pengguna.

Microsoft Access dapat menggunakan data yang disimpan di dalam format Microsoft Access, Microsoft Jet Database Engine, Microsoft SQL Server, Oracle Database, atau semua kontainer basis data yang mendukung standar ODBC. 


\section{PERANCANGAN SISTEM}

3.1 Alat dan Bahan Penelitian

Data mengenai penentuan jurusan berasal dari semua aspek-aspek yang menjadi dasar dalam penentuan jurusan, seperti minat, bakat, keahlian, maupun halhal lainnya yang mempengaruhi siswa dalam penentuan jurusan atau program studi. Selain itu informasi mengenai penentuan jurusan didapatkan dari bukubuku, artikel electronic book, pengalaman pribadi penulis, dan juga konsultasi langsung kepada beberapa pihak yang mendalami bidang psikologi.

Perangkat keras yang digunakan dalam pengembangan sistem ini adalah satu unit laptop dengan spesifikasi :

a. Prosesor Intel Core 2 Duo @ 2.40 $\mathrm{GHz}$

b. RAM 2 GB

c. HDD 250 GB SATA

Dalam menjalankan aplikasi ini, spesifikasi perangkat keras yang digunakan tidak harus menggunakan spesifikasi diatas, tetapi juga bisa menggunakan spesifikasi dibawahnya atau diatasnya.

Perangkat lunak yang dibutuhkan dalam pengembangan sistem ini antara lain :

a. Microsoft Windows 7 Ultimate 32-bit

b. Microsoft Visual Studio 2010

c. Microsoft Office Access 2010

\subsection{Langkah Penelitian}

Dalam pembuatan dan perancangan Sistem Cerdas Penentuan Jurusan di Universitas Diponegoro yang dijadikan topik dalam tugas akhir ini, langkah-langkah yang dilakukan adalah sebagai berikut, seperti yang terdapat pada Gambar 1.

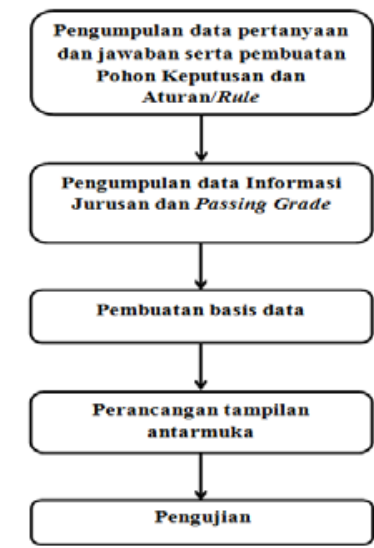

Gambar 1 Langkah Perancangan Sistem

Penjelasan mengenai diagram langkahlangkah pembuatan Sistem Cerdas Penentuan Jurusan di Universitas Diponegoro akan dijelaskan lebih lanjut pada masing-masing langkahnya sebagai berikut.
1. Pengumpulan data Pertanyaan dan Jawaban serta Pembuatan Pohon Keputusan dan Aturan/Rule

Pada langkah ini dilakukan pengumpulan data yang kemudian akan digunakan sebagai pertanyaan-pertanyaan beserta jawabannya dalam melakukan penentuan jurusan, setelah itu baru akan dibuat Pohon Keputusan yang berisikan kode-kode dari pertanyaan dan jawaban yang telah dibuat sebelumnya, lalu dari situ dapatlah ditentukan rule atau aturan untuk sebagai jalannya aliran pertanyaan pertanyaan apa saja yang masing-masing jurusan.

2. Pengumpulan Data Informasi Jurusan dan Passing Grade

Pada langkah ini dilakukan pengumpulan data mengenai masing-masing jurusan yang ada di Universitas Diponegoro yang berjumlah sebanyak 47 Jurusan atau Program Studi. Data yang dikumpulkan antara lain meliputi, nama ketua jurusan, tahun didirikan, akreditasi, website, nomor telepon, gelar sarjana, dan prospek kerja setelah lulus dari jurusan tersebut. Passing Grade digunakan sebagai acuan untuk peringkat jurusan, yang dikelompokkan berdasarkan IPA (Ilmu Pengetahuan Alam) dan IPS (Ilmu Pengetahuan Sosial).

3. Pembuatan Basis Data

Dalam pembuatan DFD (Data Flow Diagram) dimulai dengan diagram konteks yang menggambarkan hubungan antara sistem cerdas penentuan jurusan di Universitas Diponegoro dengan pengguna.

Pengguna adalah orang yang dapat menjalankan sistem, melakukan penentuan jurusan, menyimpan dan mengosongkan data pengguna, juga melihat info serta peringkat jurusan IPA dan IPS. Diagram konteks sistem cerdas penentuan jurusan di Universitas Diponegoro dapat dilihat pada Gambar 2 di bawah ini.

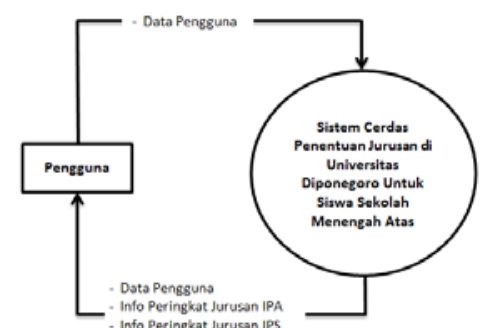

Gambar 2 Diagram Konteks 


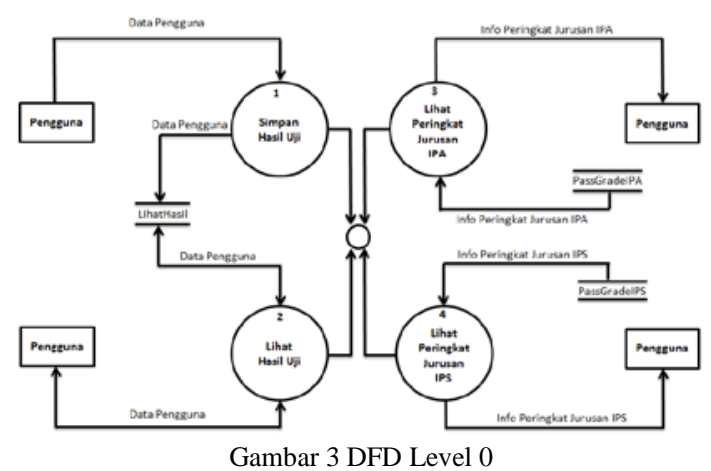

Diagram Konteks di atas dapat dijabarkan menjadi lebih rinci lagi yang disebut DFD level 0. Pada DFD 0 tersebut terdapat 4 proses, yaitu :

1. Proses 1, Simpan Hasil Uji. Proses ini hanya dapat dilakukan setelah pengguna melakukan penentuan jurusan dan mendapatkan rekomendasi jurusan. Dalam proses ini pengguna memasukkan nama, dan asal sekolah untuk disimpan dalam tabel LihatHasil.

2. Proses 2, Lihat Hasil Uji. Dalam proses ini pengguna dapat melihat dan mengosongkan data-data pengguna yang sebelumnya telah tersimpan dalam tabel LihatHasil, berupa nama, asal sekolah, dan jurusan yang direkomendasikan oleh sistem.

3. Proses 3, Lihat Peringkat Jurusan IPA. Dalam proses ini pengguna aplikasi sistem cerdas ini dapat melihat peringkat dari jurusan-jurusan IPA di Universitas Diponegoro berdasarkan passing grade yang tersimpan dalam tabel PassGradeIPA.

4. Proses 4, Lihat Peringkat Jurusan IPS. Dalam proses ini pengguna aplikasi sistem cerdas ini dapat melihat peringkat dari jurusan-jurusan IPS di Universitas Diponegoro berdasarkan passing grade yang tersimpan dalam tabel PassGradeIPS.

\subsection{Tahap Perancangan}

1. Perancangan Basis Pengetahuan

Basis pengetahuan merupakan kumpulan pengetahuan suatu bidang tertentu pada tingkat pakar dalam format tertentu. Pengetahuan ini diperoleh dari akumulasi pengetahuan berbagai sumber, seperti buku-buku, artikel electronic book, pengalaman pribadi penulis, dan juga konsultasi langsung kepada beberapa pihak yang mendalami bidang psikologi. Perancangan basis pengetahuan dalam sistem cerdas ini berupa pertanyaan dan jawaban yang telah dihimpun, disusun, dan diseleksi oleh penulis melalui berbagai sumber tersebut, yang tersusun dalam bentuk tabel.

Terdapat 4 buah tabel, antara lain adalah, tabel pertanyaan IPA dan tabel jawaban IPA yang berisi 155 pertanyaan dan jawaban, serta tabel pertanyaan IPS dan tabel jawaban IPS yang berisi 65 pertanyaan dan jawaban. Semua pertanyaan tersebut telah tersimpan dalam sistem dan digunakan untuk menentukan jurusan yang direkomendasikan kepada pengguna.

Pertanyaan tersebut diberi kode-kode tertentu, yaitu IPAxx untuk pertanyaan IPS ke$\mathrm{xx}$, IPSxx untuk pertanyaan IPS ke-xx, Jxx untuk jawaban IPA/IPS ke-xx, PA untuk pertanyaan awal, serta PNIPA dan PNIPS untuk pertanyaan nilai IPA dan IPS.

2. Perancangan Mesin Inferensi dan Representasi Pengetahuan

Mesin inferensi forward chaining yang digunakan dalam sistem ini bertujuan untuk menentukan jurusan yang sesuai untuk pengguna dan memberikan hasil berupa jurusan yang direkomendasikan kepada pengguna oleh sistem. Ada beberapa cara dalam merepresentasikan suatu penalaran/inferensi dalam merancang sebuah sistem pakar diantaranya adalah menggunakan pohon keputusan.

Representasi pengetahuan bertujuan untuk mengorganisasikan basis pengetahuan dalam bentuk dan format tertentu untuk bisa dimengerti oleh komputer. Basis pengetahuan merupakan sekumpulan pengetahuan yang dihubungkan dengan sejumlah permasalahan yang digunakan dalam sistem kecerdasan buatan. Basis pengetahuan ini merupakan analisa data yang akan digunakan dalam pembangunan sistem. Basis pengetahuan digunakan untuk penarikan kesimpulan yang merupakan hasil dari proses pelacakan. Pada perancangan basis pengetahuan sistem pakar ini konklusi adalah rekomendasi jurusan dan premis adalah pertanyaan beserta jawabannya, sehingga bentuk pernyataannya adalah :

$\operatorname{IF}[$ pertanyaan1 (jawaban1) ]AND [ pertanyaan2 $(j$ awaban1) ]...THEN [keputusan/rekomendasi]

Kemudian aturan ini diterapkan kedalam sistem ini dimana terdapat 47 jurusan S1 yang ada di Universitas Diponegoro sebagai hasil akhir atau hasil rekomendasinya, dimana pada setiap hasil memiliki lebih dari satu rule atau aturan. Rule ini juga dibuat dengan memperhatikan jalannya pertanyaan yang ada pada pohon keputusan dari sistem cerdas penentuan jurusan di Universitas Diponegoro ini. 


\section{HASIL PENELITIAN}

4.1 Pengujian Antarmuka

Pengujian antarmuka menggambarkan tampilan dari aplikasi yang dibangun yaitu implementasi antarmuka sistem cerdas penentuan jurusan di Universitas Diponegoro

1. Halaman Awal

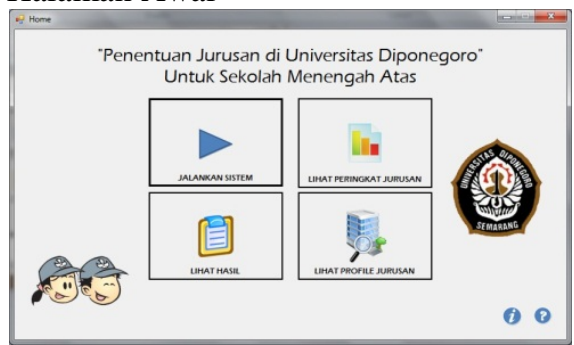

Gambar 4 Tampilan Halaman Awal

\section{Jalankan Sistem}
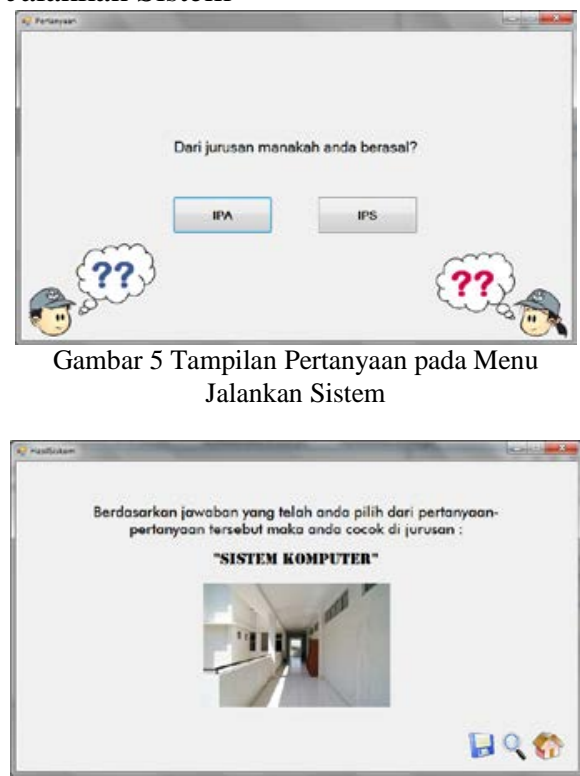

Gambar 6 Tampilan Halaman Jurusan Rekomendasi pada Menu Jalankan Sistem

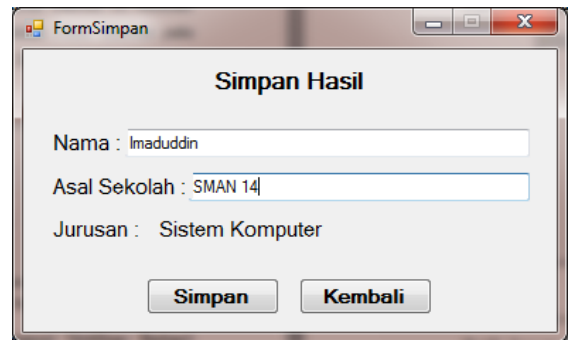

Gambar 7 Tampilan Form Simpan Hasil pada Menu Jalankan Sistem
3. Lihat Profil Jurusan

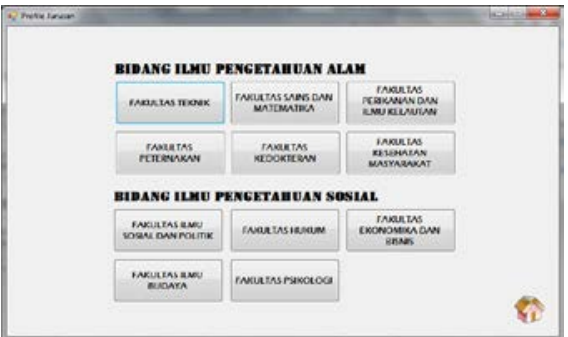

Gambar 8 Tampilan Halaman Lihat Profil Jurusan

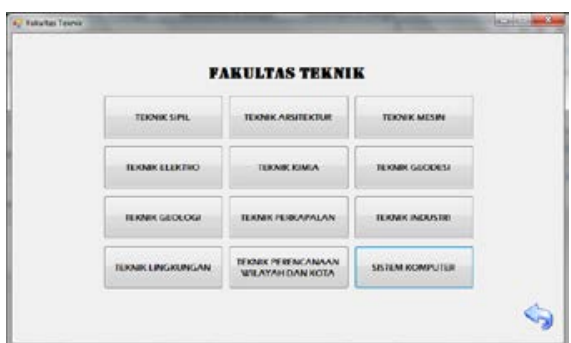

Gambar 9 Tampilan Halaman Fakultas dalam menu Lihat Profile Jurusan

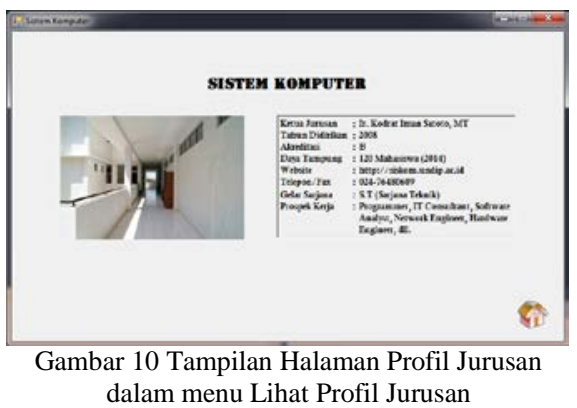

4.Lihat Peringkat

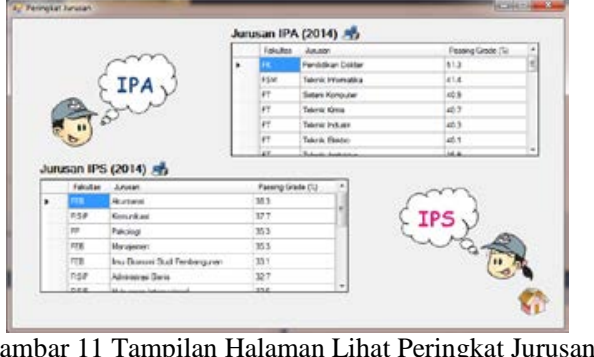

Gambar 11 Tampilan Halaman Lihat Peringkat Jurusan

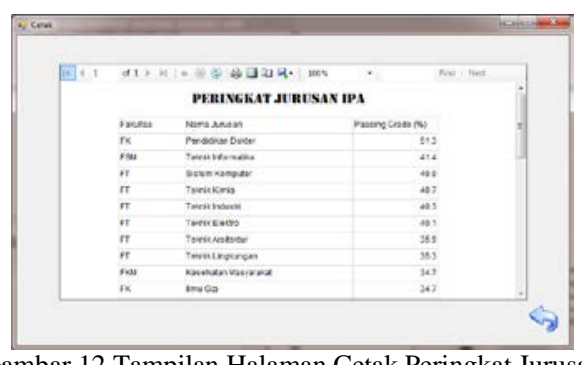

Gambar 12 Tampilan Halaman Cetak Peringkat Jurusan IPA 


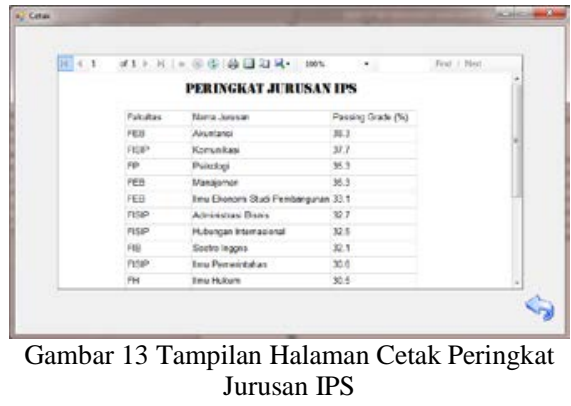

5.Lihat Hasil

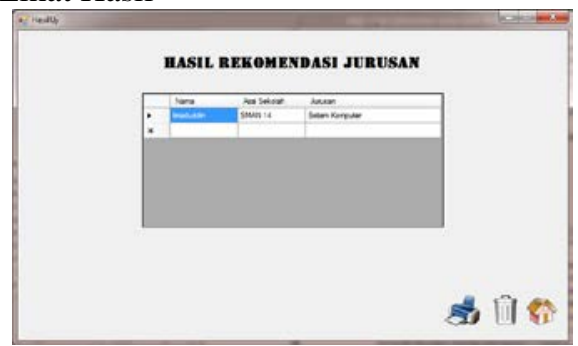

Gambar 14 Tampilan Halaman Lihat Hasil

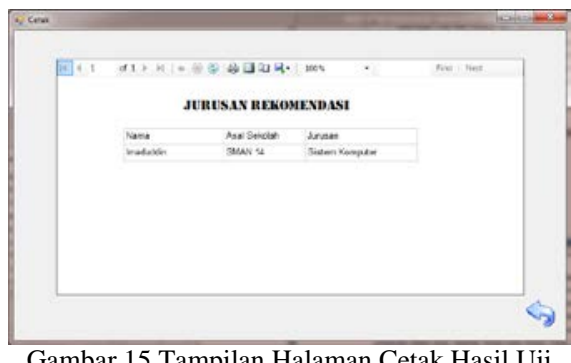

6. Bantuan

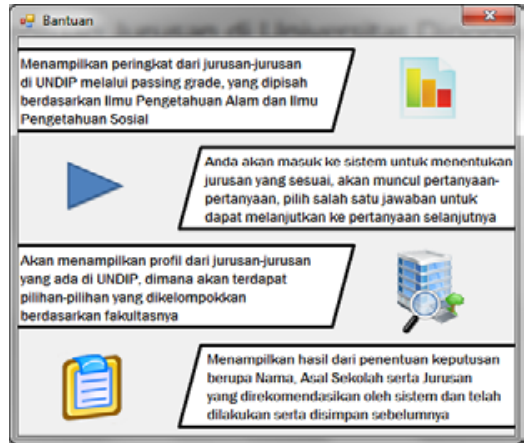

Gambar 16 Tampilan Halaman Bantuan

7. Tentang Program

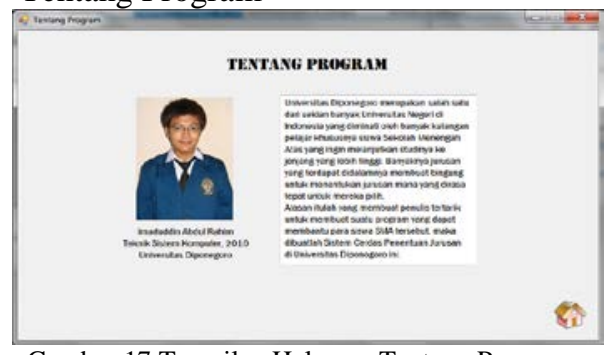

Gambar 17 Tampilan Halaman Tentang Program

\subsection{Pengujian Sistem}

Proses pengujian menggunakan metode black-box, yang merupakan pengujian yang dilakukan dengan cara menguji aplikasi dengan memasukkan data ke dalam form-form yang telah disediakan. Pada tahap ini merupakan kelanjutan dari tahap implementasi, yang berfokus pada persyaratan fungsional perangkat lunak. Pengujian ini memungkinkan perekayasa sistem mendapatkan serangkaian kondisi input yang sepenuhnya semua persyaratan fungsional untuk suatu program dibagi menurut fungsi dari masing-masing menu sesuai dengan kegunaannya. Bentuk pengujian berupa cara pengguna menggunakan aplikasi, berikut merupakan tabel pengujian menu dari sistem.

Tabel 1 Pengujian Menu

\begin{tabular}{|c|c|c|c|}
\hline Nama Pengujian & $\begin{array}{c}\text { Bentuk } \\
\text { Pengujian }\end{array}$ & Hasil Yang Diharapkan & $\begin{array}{c}\text { Hasil } \\
\text { Pengujian }\end{array}$ \\
\hline $\begin{array}{c}\text { Pengujian } \\
\text { jalankan sistem }\end{array}$ & $\begin{array}{c}\text { Mengklik tombol } \\
\text { Jalankan Sistem }\end{array}$ & $\begin{array}{c}\text { Menampilkan form } \\
\text { pertanyaan-pertanyaan }\end{array}$ & Berhasil \\
\hline $\begin{array}{c}\text { Pengujian } \\
\text { peringkat jurusan }\end{array}$ & $\begin{array}{c}\text { Mengklik tombol } \\
\text { Lihat Peringkat } \\
\text { Jurusan }\end{array}$ & $\begin{array}{c}\text { Menampilkan form } \\
\text { Peringkat Jurusan }\end{array}$ & Berhasil \\
\hline $\begin{array}{c}\text { Pengujian lihat } \\
\text { hasil }\end{array}$ & $\begin{array}{c}\text { Mengklik tombol } \\
\text { Lihat Hasil }\end{array}$ & $\begin{array}{c}\text { Menampilkan form Lihat } \\
\text { Hasil Rekomendasi yang } \\
\text { telah disimpan sebelumnya }\end{array}$ & Berhasil \\
\hline $\begin{array}{c}\text { Pengujian lihat } \\
\text { peringkat jurusan }\end{array}$ & $\begin{array}{c}\text { Mengklik tombol } \\
\text { Lihat Peringkat } \\
\text { Jurusan }\end{array}$ & $\begin{array}{c}\text { Menampilkan form } \\
\text { Peringkat Jurusan } \\
\text { berdasarkan passing grade }\end{array}$ & Berhasil \\
\hline $\begin{array}{c}\text { Pengujian lihat } \\
\text { bantuan }\end{array}$ & $\begin{array}{c}\text { Mengklik tombol } \\
\text { Bantuan }\end{array}$ & $\begin{array}{c}\text { Menampilkan form } \\
\text { Bantuan }\end{array}$ & Berhasil \\
\hline $\begin{array}{c}\text { Pengujian lihat } \\
\text { informasi program }\end{array}$ & $\begin{array}{c}\text { Mengklik tombol } \\
\text { Tentang Program }\end{array}$ & $\begin{array}{c}\text { Menampilkan form } \\
\text { Tentang Program }\end{array}$ & Berhasil \\
\hline
\end{tabular}

\section{KESIMPULAN \& SARAN}

\subsection{Kesimpulan}

Dari hasil pengujian dan analisis aplikasi Sistem Cerdas Untuk Menentukan Peminatan Jurusan di Universitas Diponegoro Bagi Siswa Sekolah Menengah Atas maka dapat disimpulkan hal-hal sebagai berikut:

1. Berdasarkan pengujian, aplikasi dapat membantu mempermudah para pengguna khususnya para siswa Sekolah Menengah Atas yang ingin melanjutkan ke jenjang pendidikan yang lebih tinggi dalam menentukan jurusan atau program studi di Universitas Diponegoro.

2. Aplikasi juga membantu mempermudah para pengguna khususnya para siswa Sekolah Menengah Atas yang ingin melanjutkan ke jenjang pendidikan yang lebih tinggi dalam mencari informasi mengenai jurusan atau program studi dan juga peringkat berdasarkan passing grade-nya di Universitas Diponegoro.

3. Berdasarkan pengujian aplikasi, proses penyimpanan data pengguna juga berjalan baik, proses penghapus data juga berjalan dengan lancar tanpa adanya kendala.

5.2 Saran

1. Aplikasi Sistem Cerdas Untuk Menentukan Peminatan Jurusan di Universitas Diponegoro Bagi Siswa Sekolah Menengah Atas ini dapat dikembangkan lebih lanjut dengan menambahkan fitur-fitur baru yang lebih handal. 
2. Data-data mengenai informasi jurusan pada Aplikasi Sistem Cerdas Untuk Menentukan Peminatan Jurusan di Universitas Diponegoro Bagi Siswa Sekolah Menengah Atas masih kurang update, karena hampir setiap tahunnya terjadi perubahan, untuk itu diperlukan pembaruan data secara berkala.

3. Melakukan backup data secara berkala untuk menanggulangi jika terjadi kehilangan maupun kerusakan data dapat dikembangkan menjadi sebuah fitur baru yang mendukung keterjaminan data pada sistem.

\section{DAFTAR PUSTAKA}

Aditya, Primananda Arif. 2008. Dasar-dasar Pemrograman Database Desktop dengan Visual Basic.net. Elex Media Komputindo. Jakarta.

Arhami, Muhammad. 2005. Konsep Dasar Sistem Pakar. Penerbit Andi. Yogyakarta.
Hartati, Sri dan Sari Iswanti. 2008. Sistem Pakar dan Pengembangannya. Graha Ilmu. Yogyakarta

Hidayatullah, Priyanto. 2014. Visual Basic .NET Membuat Aplikasi Database dan Program Kreatif. Penerbit Informatika. Bandung.

Kusrini. 2006. Sistem Pakar Teori dan Aplikasi. Penerbit Andi. Yogyakarta.

Kusumadewi, Sri. 2003. Artificial Inteligence Teknik dan Aplikasi Edisi Pertama. Penerbit Graha Ilmu.Yogyakarta.

Pamungkas, Arthur Kemal dan Rahadian Wahyuaji. 2013. Cara Memilih Program Studi di Perguruan Tinggi. Elex Media Komputindo. Jakarta.

Turban, Efrain. 2005. Decision Support Systems and Intelligent Systems. Penerbit Andi. Yogyakarta.

Daya Tampung UNDIP.

http://penerimaan.undip.ac.id/snmptn/dayatampung-undip/

Diakses pada 10 September 2014

Monitoring Akreditasi Prodi UNDIP. http://pssb.undip.ac.id/cekakreditasi/

Diakses pada 10 September 2014 